Mr. K. A. Britwum: Kwadwo Adinkra of Gyaman: a study of the relations between the

Brong kingdom of Gyaman and Asante, 1800-1818.

Dr. Florence Dolphyne: Brong (Bono) dialects.

Mr. K. O. Odoom: Islam in the Brong Region.

Dr. Kwame Daaku: Politics among the Eastern Brong.

Mr. Kwasi Boateng: Economic geography of the Brong area.

Nana Kwakye Ameyaw (Takyimankene): The origin and extent of the Bono-Manso kingdom.

Professor Posnansky and E. K. Agorsa of the Department of Archaeology, Legon, reviewed current archaeological work and findings at the famous ancient trading centre of Begho in north-western Ashanti, now the Brong-Ahafo Region. Three historical papers (Arhin, Agyeman, and Daaku) examined aspects of the relations of Ashanti with her conquered territories in the north-west and north-east and their significance for the political definition of 'Brong'. An interview by Arhin with Nana Kwakye Ameyaw, the present Takyimanhene, dealt with the origin and extent of the Bono-Manso kingdom, its defeat by Ashanti, and the fortunes of Techiman, her successor-state: the chief thought modern 'Brong' to be derived from 'Bono', the first arrivals in the area, who established the BonoManso state. Mr. K. Boateng of the Department of Geography, Legon, outlined the traditional and modern economies of the Brong-Ahafo Region. Mr. Odoom of the Institute of African Studies spoke on the coming of Islam with the establishment of the Mande tradingpost at Begho. Dr. F. Dolphyne of the Department of Linguistics, Legon, discussed differences within the Brong dialect cluster and between Brong and the other Akan dialect clusters. It is hoped that the papers will form the basis of an interdisciplinary publication on the Brong peoples.

\title{
Institute for the Study of Man in Africa
}

THE tenth annual Raymond Dart Lecture was delivered on s February 1973 by Professor J. D. Fage, Director of the Centre of West African Studies, University of Birmingham, and a member of the International African Institute's Executive Council. The subject of the lecture was 'States and Subjects in Sub-Saharan African History'.

\section{University of Ibadan: Behavioural Science Research Unit}

THE University of Ibadan Behavioural Science Research Unit was established in 1967 with a grant from the Ford Foundation. Professor T. O. Lambo, former Vice-Chancellor of the University of Ibadan, is the Director of Research which is concerned mainly with the response of the individual to the challenge and stress arising from the social distuption brought about by urbanization, industrialization, and migration in the densely populated areas of Western Nigeria. The Unit is prepared to undertake or collaborate in cross-cultural research projects and will also assist in the collection of data in Nigeria for foreign research workers. Inquiries should be addressed to Dr. C. G. M. Bakare, University of Ibadan, Ibadan, Nigeria.

\section{The Nigerian Political Science Association}

The Nigerian Political Science Association was established at an inaugural meeting at the University of Ibadan in January 1973, attended by the Federal Commissioner for Education, Chief Abdul Eke, a former foundation student and later Registrar of the university. In his speech he singled out three important areas of study for political scientists : the indigenous systems before independence; the intentions of the British colonialists in Nigeria in the colonial period; and post-colonial politics. Papers discussed included Transition from 
Military Rule, Political Orientations to the Military Regime in Western State, and The Growth of Northern Leadership 1939-5 I. Professor Billy J. Dudley of the Department of Political Science, Ibadan, is to head the seven-man executive of the new association.

\section{The Institute for Developing Countries in Zagreb}

The Institute for Developing Countries (until 1971 the Africa Research Institute) was founded in 1963 by Zagreb University and the Chamber of Commerce of the Socialist Republic of Croatia and now covers Latin America and Asia as well as Africa. The Director is Ivo Sarajzič and the staff of fourteen research workers is engaged in studies of the economy, sociology, politics, and culture of developing countries and works in close collaboration with specialists from Yugoslavia and other European countries. Since 1966 the Institute has published a monthly review on economic movements in developing countries and a number of monographs, mainly on African economics, in the Croato-Serbian language.

\section{The African Society in Finland}

ThE African Society in Finland (Mechelininkatu 8 A I2, 00100 Helsinki 10) was established in 1964. Its purpose is to promote the knowledge of African countries, to supply information and to encourage and support development assistance and research on Africa in Finland. The society also aims to grant research or travel fellowships and exchange scholarships and to co-operate with other associations concerned with African studies. The Chairman is Pavo Aarnio and there are at present some 280 members.

\section{The Preservation of African Antiquities}

UNDER an agreement between Unesco, the Nigerian government, and the U.N. Development Programme, a centre has been established at Jos to train specialists in the techniques of preserving African antiquities. The centre, successor to a Unesco pilot project in training museum technicians, is housed in a new building equipped for teaching and laboratory work. The University of Ibadan also plans to establish a chair in museography at its Jos campus. First courses start in September 1973 and will cover modern methods of preservation and restoration and other museum techniques. The first sixteen participants are to be chosen by governments of Unesco member states and teaching staff will be recruited internationally. A number of fellowships will be awarded annually for study at the centre to students from African countries.

\section{INADES: Weekly Bibliographical Bulletin (Fichier-Afrique)}

INADES (Institut Africain pour le Développement Économique et Social, Abidjan) publishes a weekly bibliographical index in French, printed on cards for filing, containing selected items from 250 periodicals covering development problems, economics, history, politics, ethnology, and sociology (particularly social change). The bulletin deal swith the whole of Africa with special emphasis on French-speaking countries.

The annual subscription (air mail) is $\$ 55 ; 250$ F.; 12,000 F CFA. Address : INADES, B.P. 8008, Abidjan, Ivory Coast. C.C.P. Paris, No. 22194 88. (Société Générale de Banques en Côte d'Ivoire-S G B CI-Abidjan, compte No. II3-065. 555-93.)

\section{West Virginia University: Microfilm Collection of East African Agricultural Periodicals}

THE library of West Virginia University has, with the co-operation of the Kenya Ministry of Agriculture, the Macmillan Library in Nairobi, and the Kenya National Archives, secured microfilm copies of a number of relatively hard to obtain periodicals published in 